\title{
Factors Influencing Credit Decision for Lending SMEs: A Case Study on National Bank of Egypt
}

\author{
Ekhaa Boushnak, Mohamed A. Rageb, Aiman A. Ragab, Ahmed M. Sakr \\ Arab Academy for Science, Technology and Maritime Transport, Alexandria, Egypt \\ Email: ekhaa.w.boushnak@gmail.com,raghebmm@aast.edu
}

How to cite this paper: Boushnak, E., Rageb, M.A., Ragab, A.A. and Sakr, A.M. (2018) Factors Influencing Credit Decision for Lending SMEs: A Case Study on National Bank of Egypt. Open Access Library Journal, 5: e4996.

https://doi.org/10.4236/oalib.1104996

Received: October 23, 2018

Accepted: November 17, 2018

Published: November 20, 2018

Copyright $\odot 2018$ by authors and Open Access Library Inc.

This work is licensed under the Creative Commons Attribution International License (CC BY 4.0).

http://creativecommons.org/licenses/by/4.0/

(c) (i) Open Access

\begin{abstract}
Small and Medium Enterprises (SMEs) play a vital role in the global economy. It had a major part in creating jobs and as a source of social stability, either there is major contribution for SMEs in Egypt as it faces great economy challenges that need cooperation from all parties. However, access to finance is still one of the greatest obstacles facing SMEs all over the world and prevents them from developing. This research is important to fill the research gap which appears in the limited researches that present main factors adopted by the credit decision maker in Banks for evaluating the SMEs. Purpose of this study is to make a progress for filling the gap through exploring these factors. The research was guided by the following research questions: What are the factors that influence credit decision making for lending SMEs? What framework is available to improve the SMEs lending process in the Egyptian Banks? Case study strategy and Quantitative Methods were adopted. Data was gathered from 313 structured questionnaires answered by credit risk and marketing employees from National Bank of Egypt (NBE). The author tested five hypotheses on the relationship between variables, with the SPSS "Package for the Social Sciences" and AMOS "Analysis of a Moment Structure". They were utilized to interpret the results. The findings provide evidence that factors, like Owner/Manager Character, Capacity, Firm Capital Size, Credit Bureau Report with the availability and Credibility of Financial statements, had a huge impact on Credit Decision for lending SMEs. From the research results, there was framework designing to enhance the credit risk assessment process, which could decrease the uncertainty and time consuming in the lending decision and it might reflect positively on the national economy development.
\end{abstract}

\section{Subject Areas}

Business Analysis, Financial Reporting 


\section{Keywords}

Credit Assessments, Credit Decision, Small and Medium-Sized Enterprises (SMEs), Egypt

\section{Introduction}

The world is witnessing dynamic changes in the international business environment. The role of SMEs playing in today's global economies is a highly interesting matter, as they are primary driving forces for job creation, decrease the unemployment, income generation, and have a grand role in the innovation and technological progress. SMEs and micro-enterprises comprise more than $95 \%$ of firms and represent $50 \%$ to $66 \%$ of non-farm employment and Gross Domestic Product worldwide [1]. [2] reported that approximately $70 \%$ of all SMEs in developing markets lack access to finance that makes it difficult to survive or expand.

In Africa, the financial gap for formal SMEs was projected to be US\$1.2 trillion, while the financial gap for the informal was US\$1.4 trillion. IFC and McKinsey brought up that nearly $45 \%$ to $55 \%$ of the MSMEs in emerging markets do not approach the needed finance, which should support them and help them to grow and expand [3]. Therefore, enhancing access to finance SMEs may improve their capability to thrive, in addition to reducing unemployment [4].

However, from a supply point, the banks aim to maximize their profit, so they seek simultaneously the highest possible return on assets "loans", with high quality investment, and reduce the lending risk that might be achieved by dealing with borrowers who can pay a high interest rate and are unlikely to default. These factors make it difficult for SMEs quest to borrow from banks [5]. The finance gap appears, when bank requirements do not meet from customers, which influences the lending decision negatively and prevents SMEs from borrowing. The majority of banks are at risk towards SMEs as there is a lack of data about their credit history, business transactions, financial performance, even with no official documents to trace, so banks depend much on credit employees efficiency and experience for enterprises assessment in the lending process.

The availability of Bank finance for SMEs is an important research topic for the academics, with a great importance for the economists and the governments around the globe. The research gap appears in the limited articles and researches that present an appropriate variety of factors commonly used by the credit decision maker in banks for evaluating the SMEs, and no research focuses on public banks in Egypt. Though they are representing the majority of market share for lending SMEs, the following two questions were identified and the corresponding propositions formulated. What are the factors influencing Credit Decision Making for lending SMEs? What is the available framework using to improve the SMEs lending process in the Banking Sector? The conclusion of this study is 
particularly noteworthy because it provides advices for improving efficiency, reducing the uncertainty and time consuming for preparing the credit proposal in banks. Furthermore, the research may provide the knowledge for SMEs to know: what the bank's requirements are and how they have been evaluated, which will aid to enhance their performance and shift to the official market, and may improve granting loans for both parties (borrowers \& lenders).

\section{Literature Review}

SME access to finance was selected as the topic of this paper, as there is a growing recognition of the major obstacles that hindered SMEs from doing their successful role in developing the economies around the world, and search for methods of treatment, such as this aim might be achieved through Identify the Factors Banks rely on when assessing SMEs, during Credit Decision making for lending, then develop a framework for facilitating the SMEs lending process.

\subsection{SMEs Definitions and Importance}

There are many definitions for SMEs across the world, either it has been changed from time to time according to market and economic conditions. [6] brought up that there are over 55 definitions for micro enterprises and 75 Definitions for SMEs [7]. Characterized small enterprises as having fewer than 200 workers and the revenue or sales is between 1 million and less than 50 million EGP (Less than US $\$ 2.7$ million in revenue) the medium enterprises are defined as having less than 200 workers the revenue is between 50 million and less than 200 million EGP, less than US\$11 million in revenue. World trade Defined SMEs as it meets two of the accompanying three requirements, first it has less than 300 workers, second if it has fewer than US $\$ 15$ million in assets, third if it has fewer than US\$15 million in yearly revenue, several nations utilize a measure of assets to define the SME; for instance, in the US, SME is defined when the firms total assets is less than US\$9 million in total assets [8].

The EU the SME is divided into small enterprises that has less than 50 employees and less than $€ 10$ million annual sales [9]. As a general rule the World Bank characterizes SME as having under 300 workers, Sales around US\$15 million and Total assets US\$15 million. SMEs has a critical role in this development stage, either the majority of big corporate depends on them as a supplier for production inputs. [10] described SMEs as essentials in accomplishing the Sustainable goals by promoting sustainable economic growth, providing a suitable work for all. Promoting sustainable industrialization and encouraging innovation, and reducing income inequalities. [11] reported that SMEs in Uganda constitute over $90 \%$ of the private sector, contribute $75 \%$ of the country's GDP. [12] stated that SMEs present $85 \%$ of the Kenyan work force they work across, they add value to the economy.

\subsection{SMEs in Egypt}

SMEs are essential segment of the Egyptian economy, simply like numerous 
other developing nations, Total number of Small and Micro Firms in Egypt came to 2.4 million enterprises, with 6.3 million employees, and the total production reached EGP 403.8 billion, The Medium enterprise number was 4.7000 firms, with 322.6 thousand workers, and the total production was EGP 98.7 billion, as per the economic statistics data for the year 2012/2013 [13]. [14] explored that SMEs in Egypt are suffer from financing constraints, only 7\% of new investments and working capital is financed through the banking sector in Egypt, This compares to $26 \%$ globally, Micro Small and Medium Enterprises loans represent only 6 percentage of total bank loans which around 1\% of GDP, The shortcomings of the legal, financial infrastructure, the credit information systems and no matching between the education system with job market requirements, they are the main reason to limit the Banks finance in Egypt.

These elements drove banks to expand risk averse to private sector lending and do not apply credit risk standard. Rather, they depend on security necessities, which are often frequently hard to meet, there are in excess of 400 microfinance foundations in Egypt, and they are almost reached $20 \%$ to $50 \%$ of the qualified demand in this segment. [15] affirmed that SMEs in Egypt constitutes roughly $2.5 \mathrm{~m}$ projects, representing $99 \%$ of non-agricultural private segment, Moreover, these enterprises give around $75 \%$ of jobs, and around $80 \%$ of the GDP and contribute to $75 \%$ of aggregate nation exports, small businesses contribute over $10 \%$ of industrial production in Egypt, while medium enterprises give $40 \%$.

[16] explained that Egyptian MSMEs face a numerous of challenges such as the political instability and the economic downturn followed the 2011 uprisings, The absence of a well functioning labour market, lack the knowledge and management expertise, along with high number of state owned enterprises, MSMEs also suffer from the absence of the alliances with large firms, The private sector in Egypt received only $10 \%$ of the available financing from the banking sector and $6 \%$ of small and medium firms have access to bank loans, compared to nearly $18 \%$ of large firms, which resulting in an untapped potential for productivity gains. In Egypt a few SMEs work in the mining sector, Almost $90 \%$ of these enterprises is concentrated in just two sectors the manufacturing sector are $51.1 \%$, furthermore, the wholesale trade sector present $40.5 \%$.

The Central Bank of Egypt launched on 11th of January 2016 the initiatives to encourage SMEs for borrowing and growth. Either there are subsidized for banks in return for funding 200 EGP billion in 4 years as facilities for SMEs, Banks were supported by exempt from the reserve ratio of $14 \%$ within the limits granted, with en year 2017 there was a new modification in the initiatives, Small enterprises were granted credit facilities at a low interest rate 5\% annually without commissions, and Medium sized firms working in the fields of industry, agriculture and renewable or sustainable energy for a long-term loan was at rate of $7 \%$ annually and short-term credit facilities at a rate of $12 \%$ annually all of them without commissions. [17] pointed that the initiative succeeded in financing thousands of projects, the value of facilities granted to SMEs during the year 
2016 rose to EGP 27 billion.

\subsection{Credit Risk Assessments}

Credit risk assessment had become a particularly challenging issue for banks. It's serving as the stimulus to evaluate the credit admission or possibility business failure, in order to make aggravate initial movements. The loss resulted from the financial distress or insolvency of clients. Usually leads to a massive critique on the implementation of financial institutions due to the inadequate credit risk assessments. Those assessments considered as an early-warning detection of dangers and risks which will improve the reaction technique [18].

[19] explained that Credit risk management is monitoring system intent for continuity of the business and considered as one of the important task Banks handled. [20] observed that Banks use Nemours appraisal systems to evaluate the creditworthiness of their customers. However, loan eligibility remains the same to constantly for all banks, the Small business appraisal could be arranged into four fundamental one of a kind credit appraisal techniques "financial statement lending, asset-based lending, credit scoring, and relationship lending”. [21] identified credit risk assessment for secured facilities is a critical process in Banks to assure that borrowers pay the loans on due and to classify the bank as a well performing bank due to regulation. Credit officers use different methods to evaluate the Customers by using quantitative methods, such as financial statement full analysis, credit scoring, and using qualitative methods such as Credit analysis, which depend on evaluating factors and criteria related mainly to Customers as follows.

\subsubsection{The 5 Cs of Lending}

Is a framework utilized by credit officers to inspect the reliability of the borrowers. It's a helpful and simple risk assessment technique. They are combined of five main critical factors in one indicator, Character, Collateral, Capacity, Capital, and Conditions. [20] argued that the most common risk assessment techniques utilized within Kenya were 5 Cs of lending, followed by the financial ratios. [21] affirmed that financial organizations should evaluate credit risk by utilizing collateral, condition, characters, capacity and capital measurement to control delinquency rate, so all of those factors should be thought seriously before granting loans to mitigate the risks. The $5 \mathrm{Cs}$ are popular in many nations such as Ghana, Kenya, Tanzania, India, Jordan, Lebanon, Egypt.

The first element of 5 Cs is the Owner/manager Character assessment often a paramount importance, it's utilized to assay the borrower qualities such as trustworthiness, and responsibility to repay the debt, many authors affirm the necessity for some critical element to exist in the character assessment that decision maker rely on them in the lending process, For example, education [22] [23], experience [23] [24] [25], Age [26] [27] [28], gender [27] [29], ethnic [28] [30]. Although, some authors explain that education level [6] [26] [31] business experience [6] [31], Age and gender [32] [33] had an insignificant relation to 
access to bank loans.

The second element is Collateral assessment. It is alluding the assets and property that borrower posses. It gives the lender the assurance that if the borrower defaults on paying the obligation. Thus, Banks request collateral in order to mitigate the risk of default. [34] presented that collateral was the biggest obstructions to SME financing in Zimbabwe. [35] stated there are a requirement for SMEs to give collateral to borrow. [36] affirmed that South Korea's credit guarantee schemes enhanced bank efficiency, since it assures the security of loans and shares the credit risk to the bank. [37] explained there is a relationship between access to finance by SMEs and a collateral existence, and anything could bring back the principal, in case of default. However, in many banks the collateral must be $100 \%$ or more to the loan because of high risk and for not having sufficient collateral.

The Third element is The Capacity which measures the borrower's possibility to reimburse the debit by distinguishing the source of reimbursement and future earnings from core business, So the ability of a loan applicant to repay a loan is based on cash flow and not just profitability with other sources of repayment. [38] stated that banks in Ghana in the credit evaluation process, they give a forward looking for the repayment capacity, by measuring the source of repayment and future cash flow to ensure they are enough to repay the debt. [39] found that the financial capacity of the SMEs borrower had significant impact on the probability of the loan approval. [40] defined Capacity as the real measure of the ability for the business to produce adequate cash flow to repay its obligations. In the majority of Egyptian banks, they use cash flow from operation either EBITDA (Earnings before Interest, Taxes, Depreciation and Amortization) as a source of fund which is referred for the borrower a capability to repay the debts from core business.

The fourth elements of $5 \mathrm{Cs}$ of lending are Firm Capital size. It presents the fund put into the firm by the owner. Thus, it helps to decrease or eliminate unexpected losses. [24] presented that access to finance is strongly determined by variables such as enterprise size, ownership. [32] identified that fixed assets possessed and business size is principle factors for SMEs to Access Credit from the Barclays Bank in Ghana. However, [6] explained that there are no significant relationships between the size of the business and access to finance. [41] stated that lenders are worried to lend SMEs with weak assets as they are more risky, Capital is a factor used in credit risk assessment to measure how much banks can fund the enterprise with safe involvement and not to exceed certain leverage or it will change bank relation from lenders to investors.

The Fifth elements of 5 Cs of lending are the Conditions, it comprehended the market, which borrower operates, such as state of the economy, current political situation, environmental regulations, social, Legislation, government associated and technology that affect the business, These factors out of control and might affect borrower the ability to repayments. [42] affirmed that SMEs are likely to 
access bank loans in locales with higher levels of government associated. [43] explained that the banks' decision to lend SMEs might be influenced by the individual characteristics of the SME only but also by Macroeconomic factors. [44] proposed that macroeconomic elements contributed to expanded bank lending to SMEs in six emerging nations (Turkey, Argentina, Brazil, Mexico, Chile, and Poland), so to decrease the risk of uncertainty the banks study hard the macroeconomic environment and update the credit officer with the latest regulation and information to mull over when evaluate the customer and business.

\subsubsection{Business Plan}

The business plan is a fundamental management method utilizes set of documents arranged by enterprise administration to abridge its operational and financial objectives for the near the future and to indicate how they will be accomplished. [6] described there are some critical relationships between Existence of a business plan, Business ownership type, annual growth rate of an enterprise and access to finance. [45] stated that the most common criteria used in the assessment of credit risk were business plan the bank use it to evaluate whether this is profitable to lend money or not, and if it is a business that the bank wants to engage with. [45] reported that Banks in Ghana required practical business plan before preparing the proposal and lend SMEs. [46] stated that a business plan is essential in the lending for banks in South Africa.

\subsubsection{Credit Bureau Report}

It's a kind of a basic report that provide Credit officers with nonfinancial information they can't accessed about customer reputation and relationship with supplier, Customers and banks, so it will facilitate the risk assessment process. [47] revealed that credit information sharing reduces bank credit risk in both low and high income countries in Africa. [48] stated that the significance of strengthening credit information coverage and the function of private credit bureaus in Asian countries to mitigate the negative impact of unusual loan growth on bank systemic dependability. [38] explained that the banking industry of Ghana employs varied techniques to mitigate its credit risk, Such as the utilize of the credit referencing bureau. [2] reported that Credit reporting frameworks play a key part to improve the information and credit reporting, then it help decision-making when providing credit. [49] affirmed that to enhance the access to finance for SMEs it is essential to amend the credibility and reliability of the credit-information system in Egypt and consolidating the information of the public and private credit bureau for facilitate SME lending process.

\subsubsection{Availability of Legal Documents}

[43] indicated that banks' lending decision for SMEs in Nigeria influence by existing of business documentation. [50] identified the SMEs problems for access the credit because of permitting licenses and official registration documents absence, [27] described that in the Ghana enterprise registration, and official documentation/recording impact SMEs access to bank finance. [51] explained that 
Financing decisions made by interviewing banks depend on essential documents more than SME Expansion. The big issue in dealing with Egyptian SMEs is the absence of legal documents, According to governmental employees bureaucratic and no clear cooperation between ministries and government organization, also it takes time to finish.

\subsubsection{Availability and Credibility of Financial Statements}

[46] claimed that Banks required audited financial statements before lending SME, to assess their credit worthiness and decrease the risk of default. [52] affirmed that SMEs in Sri Lanka face significant constraints to access bank finance, due to the lack of reliable financial information required by banks to take a decision for granting loans. [53] described that constrain for funding SMEs came from lack of real financial information present by SMEs in Albania so banks could not evaluate the applicant performance. [50] reported that SMEs are not targeted customers for banks because there is an absence of financial records which reflect the enterprise's capacity to pay their debts. [54] Admitted that internal factors relating to SMEs lending assessment were the audited financial statements which might forecast the ability for the debt repayment. The banks seek trustworthy in the financial statement as they affirm the business will produce enough earnings to repay their obligations.

\section{Methodology}

The study used inductive strategy associated with a qualitative research approach was adopted, Data were collected by attached email questionnaire survey and was constructed after a careful review of prior researches, it was divided into 3 sections, First section asked about the respondents' Demographic Details, Second section asked about Factors that decision maker can rely on when evaluating the SME, third section evaluates the factors which the decision maker depends and used in the credit assessment for lending the SMEs. Second and third Sections were anchored on a five-point Likert scale ranging from " 1 ", strongly disagree, to " 5 ", strongly agree [55].

Case study and cross sectional were employed, The Target population was the Credit Decision makers in lending SMEs at National Bank of Egypt, as one of the pioneer banks in lending SMEs, a non-probability sample method used and the questionnaires were distributed to a sample of 313 credit Analysis, Supervisor, Manager from SMEs marketing and SMEs risk departments, at head office, branches and centers allocated in 5 zones (Cairo, Alexandria, Bahry, Upper Egypt and Suez canal region).

\section{Research Framework and Hypotheses}

The researcher will present the conceptual framework as insight on how they are created from the literature review and practical experiences from the researcher, the framework will be constructed in regards to the research questions. The Credit Decision for lending SMEs was treated as Dependent Variables, while the 
Factors affecting Credit Decision-Maker's for lending SMEs were the 5 Cs of lending "Customers Character - Collaterals - Capacity - Capital size - Conditions", and the availability of Legal Documents, Credit Bureau Report, Business Plan, availability and credibility of Financial Statements, They were the independent variable. This model used 5 hypotheses, to test within the credit employees as the decision makers for lending SMEs at National Bank of Egypt, as follow:

H1: There is a significant relation between 5 Cs (Character, Collateral, Capacity, Firm Capital size and Conditions) and the Credit Decision for lending SMEs.

$\mathrm{H} 2$ : There is a significant relation between availability for Legal document and the Credit Decision for Lending SMEs.

H3: There is a significant relation between Credit bureau report and Credit Decision for lending SMEs.

H4: There is a significant relation between Business plan and Credit Decision for lending SMEs.

H5: There is a significant relation between the availability and credibility of Financial statements and Credit Decision for lending SMEs.

\section{Results and Findings}

This section shows the results and findings of the data under study, reliability and validity were computed for the sample data. [56] described that validity refers to the ability of the questionnaire to measure what the researcher want to evaluate. [57] Argued that reliability is what the degree is the estimation free of unsteady error. It's frequently measured by Cronbach's alpha coefficient's, the level of 0.7 considered to be the minimum acceptable level [58]. The data showed KMO above 0.500, AVE above 50\%, and factor loadings above 0.4. All constructs show a Cronbach's alpha level above 0.7, which means the data are valid and reliable to be used in responding to the research hypotheses, and ready to perform the required analysis.

\section{Testing the Hypotheses}

For analysis the first research hypothesis using SEM models, the model fit indices are described as minimum discrepancy (CMIN), goodness of fit index (GFI), comparative fit index (CFI), incremental fit index (IFI), Tucker-Lewis index (TLI), root mean square of approximation (RMSEA), It was found that CMIN/df $=1.806, \mathrm{GFI}=0.930, \mathrm{CFI}=0.966, \mathrm{AGFI}=0.900$ and $\mathrm{RMSEA}=0.051$, All of the results are within the acceptable levels, The model is conducted as shown in Figure 1 where the $5 \mathrm{Cs}$ of lending are the independent variables, while the Credit Decision for lending SMEs is considered dependent variable.

Table 1 demonstrates the SEM model for the effect of the 5 Cs; Owner-Managers Characters, Collateral, Capacity, Firm Capital Size, and Conditions on Credit Decisions for lending SMEs. It was observed that there is a significant relation of Owner-Managers Character, Capacity, and Firm capital size, on Credit 


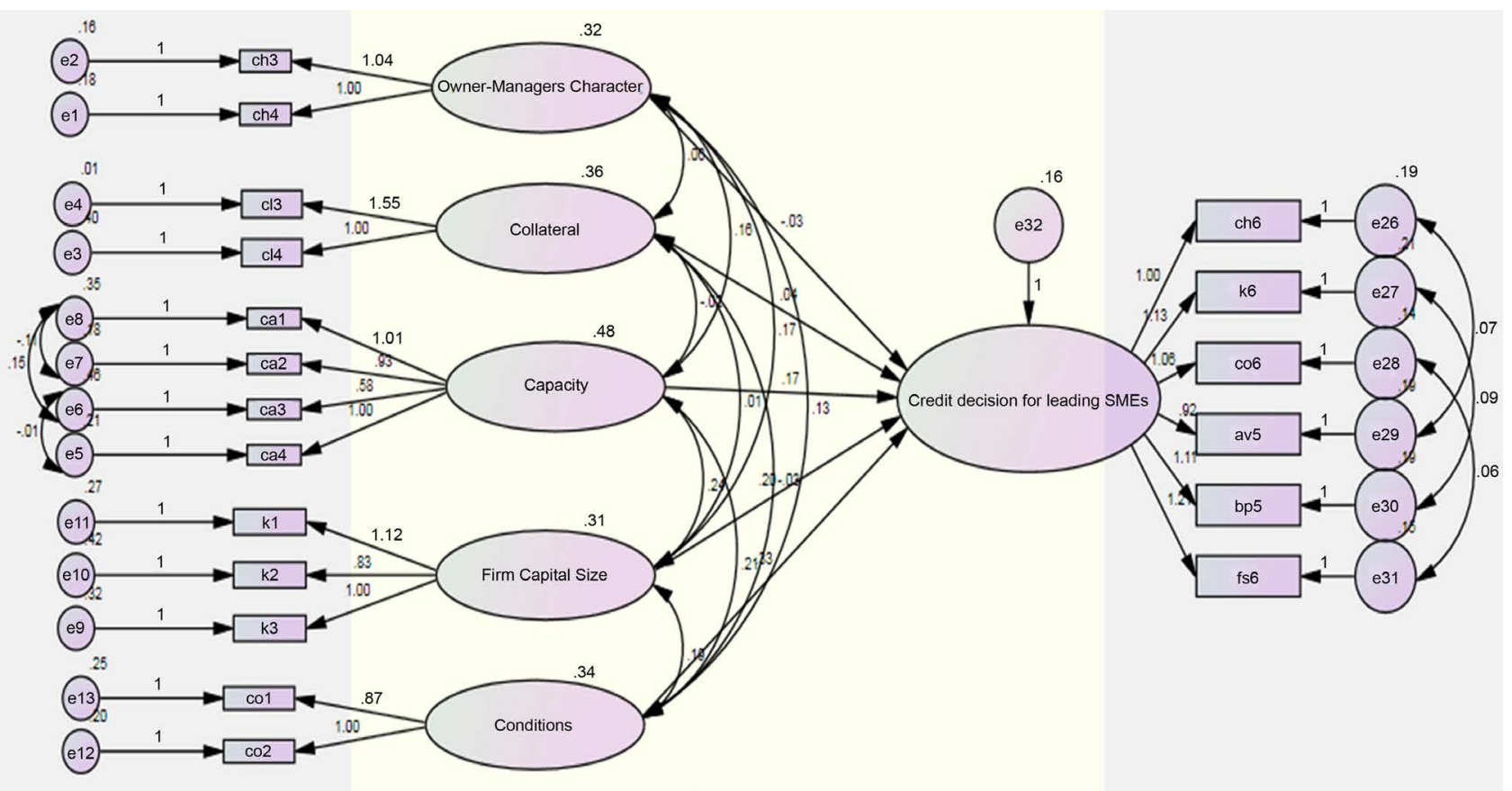

Figure 1. SEM model for the effect of 5 Cs on credit decision for lending SMEs.

Table 1. SEM model for the effect of 5 Cs on credit decision for lending SMEs.

\begin{tabular}{lccccc}
\hline & & & Estimate & P-value & R Square \\
\hline Credit Decision for lending SMEs & $<--$ & Character & 0.329 & $* * *$ & \\
Credit Decision for lending SMEs & $<--$ & Collateral & 0.041 & 0.387 & \\
Credit Decision for lending SMEs & $<--$ & Capacity & 0.168 & 0.006 & 0.426 \\
Credit Decision for lending SMEs & $<--$ & Capital Size & 0.200 & 0.039 & \\
Credit Decision for lending SMEs & $<--$ & Condition & -0.025 & 0.719 & \\
\hline
\end{tabular}

Decision for lending SMEs, with estimates of 0.329, 0.168, and 0.200 respectively and P-values of $0.000,0.006$, and 0.039 . While there is an insignificant influence of the Collateral, and Conditions, as p-value is more than 0.05 . The R Square is 0.426, which means that Owner/Managers Character, Capacity, and the Firm capital size explain $42.6 \%$ of the variation in Credit Decision for lending SMEs, Therefore, the first research hypothesis that there is a significant relationship between the 5 Cs and the Credit Decision for Lending SMEs is Partially Supported.

For analysis the other research hypothesis SEM model is conducted between the research variables; Availability of Legal Documents, Credit Bureau Report, Business Plan and Availability and Credibility for the Financial Statements as the independent variables. And The Credit Decision for Lending SMEs as the dependent variable.

The model fit indices for the measurement model are described as minimum discrepancy (CMIN), goodness of fit index (GFI), comparative fit index (CFI), incremental fit index (IFI), Tucker-Lewis index (TLI), and root mean square of 
approximation (RMSEA). It was found that $\mathrm{CMIN} / \mathrm{df}=1504, \mathrm{GFI}=0.949, \mathrm{CFI}$ $=0.984$, AGFI $=0.924$ and RMSEA $=0.040$. All are within their acceptable levels. After fitting the measurement model, the SEM analysis had been conducted as shown in Figure 2.

Table 2 demonstrates the SEM model for the effect of Availability for Legal document, Credit Bureau Report, Business Plan, and Availability and Credibility for the Financial Statements on the Credit Decisions for lending SMEs. It was observed that there is a significant relation between Credit Bureau Report, Credibility for the Financial Statements and the Credit Decision for lending SMEs, with estimates of 0.573 , and 0.127 respectively, P-values of 0.000 , and 0.001 . While there is an insignificant influence of Availability for Legal document, and Business Plan, as p-value is more than 0.05. Also, R Square is 0.452, which means that Credit Bureau Report, Credibility for the Financial Statements explain $45.2 \%$ of the variation in Credit Decision for lending SMEs.

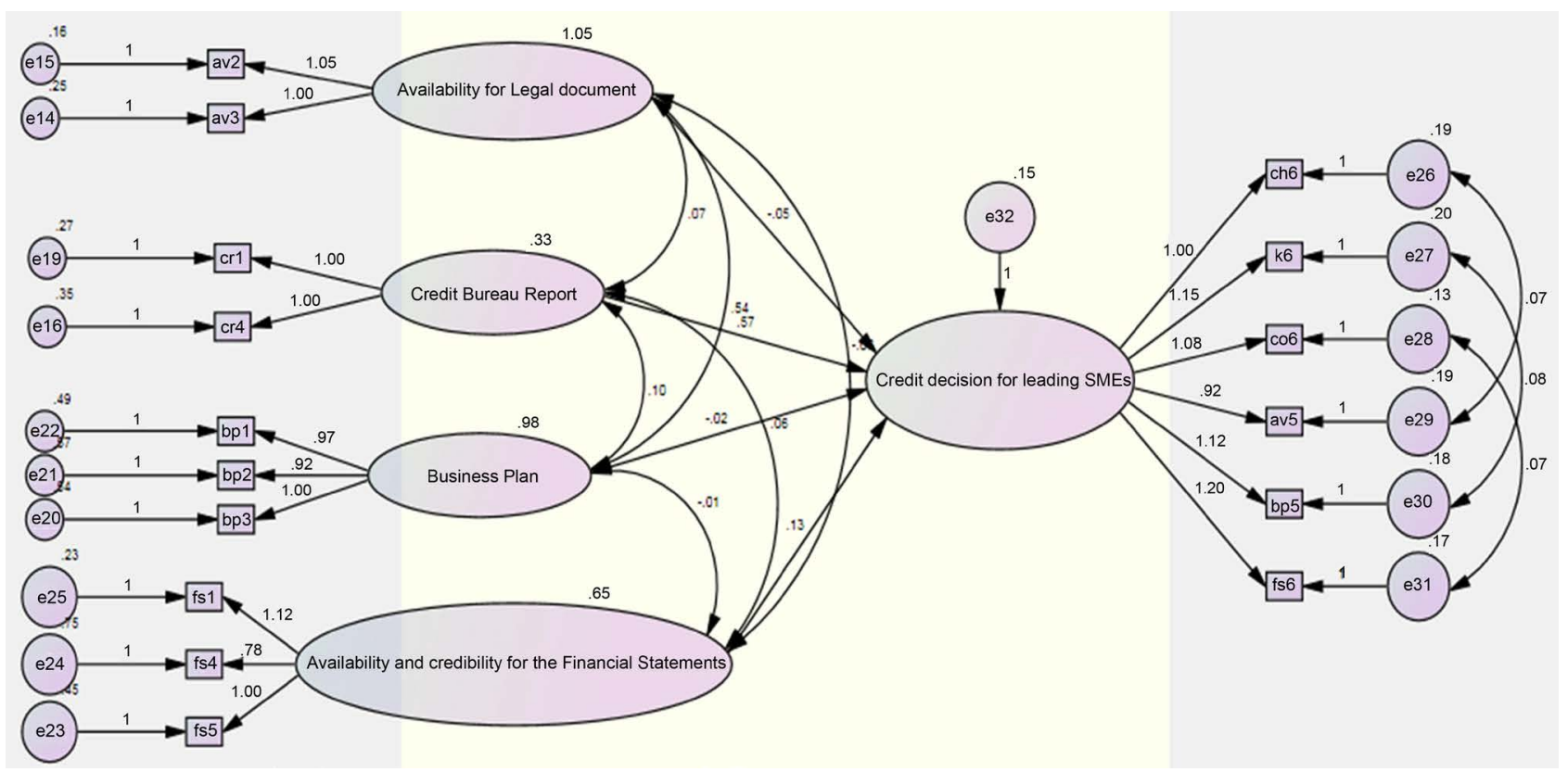

Figure 2. SEM Model for the effect of availability for legal document, credit bureau report, business plan, and availability and credibility for the financial statements on credit decision for lending SMEs.

Table 2. SEM Model for the effect of availability for legal document, credit bureau report, business plan, and availability and credibility for the financial statements on credit decision for lending SMEs.

\begin{tabular}{lccccc}
\hline & & Estimate & P-value R Square \\
\hline Credit Decision for lending SMEs & $<---$ & $\begin{array}{c}\text { Availability for Legal } \\
\text { document }\end{array}$ & -0.051 & 0.153 & \\
Credit Decision for lending SMEs & $<--$ & Credit Bureau Report & 0.573 & $* * *$ & 0.452 \\
Credit Decision for lending SMEs & $<---$ & Business Plan & -0.024 & 0.541 & 0.001 \\
Credit Decision for lending SMEs & $<---\begin{array}{c}\text { Availability and credibility for } \\
\text { the Financial Statements }\end{array}$ & 0.127 & 0.001 & \\
\hline
\end{tabular}




\section{Conclusions}

Most of the researches done on SMEs assessment have been in the context of developing countries, due to the fact that the research topic had rarely discussed within existing empirical research and presented the existing issue in SMEs finance. The key findings of the study based on the research objectives, corresponding questions and the research hypotheses that were utilized to identify the Qualitative Factors Banks, rely on when assessing SMEs during Credit Decision making for lending. The results from regression analysis with SEM Model and previous literatures were summarized in Table 3.

According to the research results, there was change in the framework design. Figure 3 shows there is significant relation between Owner-Managers Character, Capacity, Firm Capital Size, Credit Bureau Report, and the Availability and Credibility of Financial Statements with Credit Decision for lending SMEs they were drown with straight lines. While, unrelated variables, such as Collateral, Conditions, Availability for Legal Documents and Business Plan, were omitted from the framework and drown with dotted lines. Thus, the final framework might

Table 3. Summary of results.

\begin{tabular}{|c|c|}
\hline Hypothesis & Result \\
\hline $\begin{array}{l}\text { H1: There is a significant relation between the } 5 \text { Cs and the Credit Decision } \\
\text { of Lending SMEs. }\end{array}$ & Partially Supported \\
\hline $\begin{array}{l}\text { H2: There is a significant relation between availability for Legal document } \\
\text { and the Credit Decision for lending SMEs. }\end{array}$ & Rejected \\
\hline $\begin{array}{l}\text { H3: There is a significant relation between Credit bureau report and Credit } \\
\text { Decision for lending SMEs. }\end{array}$ & Supported \\
\hline $\begin{array}{l}\text { H4: There is a significant relation between Business plan and Credit } \\
\text { Decision for lending SMEs. }\end{array}$ & Rejected \\
\hline $\begin{array}{l}\text { H5: There is a significant relation between the availability and credibility of } \\
\text { Financial statements and Credit Decision for lending SMEs. }\end{array}$ & Supported \\
\hline
\end{tabular}

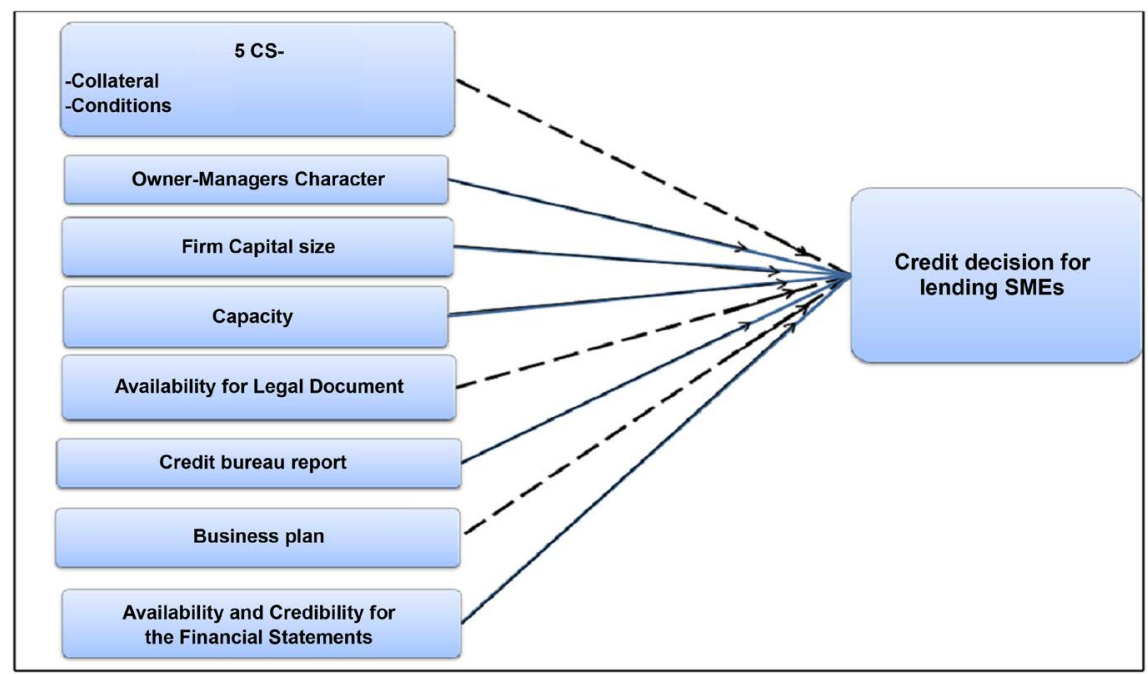

Figure 3. Quantitative factors assessment conceptual framework. 
provide a guideline for credit decision makers to concentrate on testing specific factors in every customer. However, the majority of these factors should be used as bundle, which will reduce the uncertainty and time consuming for the credit officers when preparing the credit proposal.

Furthermore, the research may provide the knowledge for SMEs to know what are banks looking and how they are evaluated, which will help them to develop, improve their performance and shift to the official market to comply with the Bank's requests.

\section{Recommendations}

Banks need to change the mindset of top management to extend finance to SME sector and train credit officers with suitable courses to deal with this type of Business, as well as developing a full range of tailored products that would facilitate the credit process and increase the flexibility of loan terms and conditions. A credit guarantee schemes should play a bigger role in spreading and dealing with banks, as a type of collateral provides the lender with a security and it mitigates the risks of defaults with affordable fees. The Central Bank and Banks should be allied with ministry of education, colleges and government organizations to launch a financial education campaign targeting at youth, children and families to gain knowledge in banking system.

Either setting training activities for SMEs to enhance their capabilities in developing business plans and feasibility studies as it will help them to manage their business, SME owners need to improve their performance and present their financial statements fairly, in order to provide the evidences for their growth, so Bank would be more trusted to funding them. Finally, the Government might take the necessary actions to facilitate the procedures for obtaining licenses and legal documents to carry out the activity and move to the official market. So all parties may gain when cooperating, which will be reflected positively on the economic development.

\section{Conflicts of Interest}

The authors declare no conflicts of interest regarding the publication of this paper.

\section{References}

[1] Mutiria, M. (2017) Factors Influencing Small and Medium Size Enterprises Access to Financing: A Case of Kiambu County, Kenya. MBA Dissertation, United States International University, Africa, Kenya.

[2] World Bank. (2015) Small and Medium Enterprises (SMEs) Finance, Improving SMEs' Access to Finance and Finding Innovative Solutions to Unlock Sources of Capital. http://www.worldbank.org/en/topic/smefinance

[3] IFC. (2013) Closing the Credit Gap for Formal and Informal Micro, Small, and Medium Enterprises.

http://www.ifc.org/wps/wcm/connect/4d6e6400416896c09494b79e78015671/Closin 
g+the+Credit+Gap+Report-FinalLatest.pdf?MOD=AJPERES

[4] Niskanen, M. and Niskanen, J. (2010) Small Business Borrowing and the Owner-Manager Agency Costs: Evidence on Finnish Data. Journal of Small Business Management, 48, 16-31. https://doi.org/10.1111/j.1540-627X.2009.00284.x

[5] Al-Anagre, A., Al-Tayeb, S. and Al-Mahrouq, M. (2005) Non-Traditional Factors Influencing the Commercial Banks Lending Decision to Small and Medium-Sized Enterprises (SMEs) in Jordan. Mu' tah Lil-Buhuth Wad-Dirasat, 20, 9-44.

[6] Bandar, W. (2016) Access to Finance by Saudi SMEs: Constraints and the Impact on Their Performance. DBA Thesis, Victoria University, Melbourne.

[7] Central Bank of Egypt, Economic Review. (2017) Economic Research Sector. Vol. 57, No. 1.

[8] Hammer, A., Jabara, C., Cardenas, E. and Wise, J. (2010) Small and Medium-Sized Enterprises: Overview of Participation in U.S. Exports. U.S. International Trade Commission, Washington DC, Investigation No. 332-508.

[9] UNESCAP. (2012) Contributions, Challenges and Prospects of SMEs. https://www.unescap.org/sites/default/files/8\%20-\%20II.\%20Contributions $\% 2 \mathrm{C} \% 20$ challenges $\% 20$ and $\% 20$ prospects $\% 20$ of\%20SMEs.pdf

[10] OECD. (2017) Enhancing the Contributions of SMEs in a Global and Digitalised Economy.

[11] Nanyondo, M. (2017) Access to Debt Finance and Its Determinants in Uganda: An Empirical Investigation of Small and Medium-Sized Enterprises (SMEs). PhD Thesis, Bournemouth University, Poole.

[12] Ndungu, C.W. (2016) Factors Affecting Credit Access among Small and Medium Enterprises in Murang'a County. Master Dissertation, University of Nairobi, Kenya.

[13] CAPMAS (2017) Egypt Statistics. http://capmas.gov.eg/HomePage.aspx

[14] European Bank (2017) Document of the European Bank, for Reconstruction and Development, Strategy for Egypt.

[15] ElBaradei, M. (2016) SMEs May Be the Key for a Better Egyptian Economy, but Does the Government Care? https://www.highbeam.com/doc/1G1-464775254.html

[16] ElSaid, H., AlSaid, M. and Zaki, C. (2014) Small and Medium Enterprises Landscape in Egypt: New Facts from a New Dataset. Journal of Business and Economics, $5,142-161$.

[17] Central Bank of Egypt (2018) About CBE. http://www.cbe.org.eg/en/AboutCBE/Pages/Overview.aspx

[18] Zhang, Q., Wang, J., Lu, A., Wang, S. and Jian, M. (2017) An Improved SMO Algorithm for Financial Credit Risk Assessment-Evidence from China's Banking. Neurocomputing, 272, 314-325. https://doi.org/10.1016/j.neucom.2017.07.002

[19] Spuchlakova, E., Valaškova, K. and Adamko, P. (2015) The Credit Risk and Its Measurement, Hedging and Monitoring. International Conference on Applied Economics, Kazan, Vol. 24, 675-681. https://doi.org/10.1016/S2212-5671(15)00671-1

[20] Chepkorir, D. (2014) The Effect of Credit Assessment Process on Repayment of Bank Loans in Commercial Banks in Kenya. Master Thesis, University of Nairobi, Nairobi.

[21] Mandala, G.N.N., Nawangpalupi, C.B. and Praktikto, F.R. (2012) Assessing Credit Risk: An Application of Data Mining in a Rural Bank. International Conference on Small and Medium Enterprises Development with a Theme, Vol. 4, 406-412. 
https://doi.org/10.1016/S2212-5671(12)00355-3

[22] Belàs, J., Vojtovič, S. and Ključnikov, A. (2016) Microenterprises and Significant Risk Factors in Loan Process. Economics and Sociology, 9, 43-59. https://doi.org/10.14254/2071-789X.2016/9-1/3

[23] Kung'u, G.K. (2015) Factors Influencing Small and Medium Enterprises' Access to Funding in Kenya: A Case Study of Westlands Division. Munich Personal RePEc Archive (MPRA), Paper No. 66633.

[24] Quartey, P., Turkson, E., Abor, J.Y. And Iddrisu, A.M. (2017) Financing the Growth of SMEs in Africa: What Are the Contraints to SME Financing within ECOWAS? Review of Development Finance, 7, 18-28. https://doi.org/10.1016/j.rdf.2017.03.001

[25] Bouazza, A.B., Ardjouman, D. and Othman Abada, O. (2015) Establishing the Factors Affecting the Growth of Small and Medium-Sized Enterprises in Algeria. American International Journal of Social Science, 4, 101-115.

[26] Ogubazghi, S.K. and Muturi, W. (2014) The Effect of Age and Educational Level of Owner/Managers on SMMEs, Access to Bank Loan in Eritrea: Evidence from Asmara City. American Journal of Industrial and Business Management, 4, 632-643. https://doi.org/10.4236/ajibm.2014.411069

[27] Nkuah, J.K., Tanyeh, J.P. and Gaeten, K. (2013) Financing Small and Medium Enterprises (SMEs) in Ghana: Challenges and Determinants in Accessing Bank Credit. International Journal of Research in Social Sciences, 2, 12-25.

[28] Nguyen, N. and Luu, N. (2013) Determinants of Financing Pattern and Access to Formal-Informal Credit: The Case of Small and Medium Sized Enterprises in Viet Nam. Journal of Management Research, 5, 240-259. https://doi.org/10.5296/jmr.v5i2.3266

[29] Wellalage, N. and Locke, S. (2017) Access to Credit by SMEs in South Asia: Do Women Entrepreneurs Face Discrimination. Research in International Business and Finance, 41, 336-346.

[30] Irwin, D. and Scott, J.M. (2010) Barriers Faced by SMEs in Raising Bank Finance. International Journal of Entrepreneurial Behavior \& Research, 16, 245-259.

[31] Abdesamed, K.H. and Abed Wahab, K. (2012) Do Experience, Education and Business Plan Influence SMEs Start-Up Bank Loan? The Case of Libya. Australian Journal of Basic and Applied Sciences, 6, 234-239.

[32] Alhassan, F. and Sakara, A. (2014) Socio-Economic Determinants of Small and Medium Enterprises' (Smes) Access to Credit from the Barclays Bank in Tamale-Ghana. International Journal of Humanities \& Social Science Studies, 1, 26-36.

[33] Gebremedihin, K.T. (2010) Determinants of Successful Loan Repayment Performance of Private Borrowers in Development Bank of Ethiopia North Region. Master Thesis, Mekelle University, Mekelle.

[34] Chidoko, C. and Matamanda, S. (2017) Accessing Formal Financing by Small and Medium Enterprises in Zimbabwe: The Case of SMEs and Banks in Chiredzi Urban. International Journal of Business and Applied Social Science, 3, 34-42.

[35] Duarte, F.D., Gama, A.P. and Esperanca, J.P. (2017) Collateral-Based on SME Lending: The Role of Business Collateral and Personal Collateral in Less-Developed Countries. Research in International Business and Finance, 39, 406-422. https://doi.org/10.1016/j.ribaf.2016.07.005

[36] Liang, L., Huang, B., Liao, C. and Gao, Y. (2017) The Impact of SMEs' Lending and Credit Guarantee on Bank Efficiency in South Korea. Review of Development Finance, 7, 134-141. https://doi.org/10.1016/j.rdf.2017.04.003 
[37] Osano, H.M. and Languitone, H. (2016) Factors Influencing Access to Finance by SMEs in Mozambique: Case of SMEs in Maputo Central Business District. Journal of Innovation and Entrepreneurship, 5, 13. https://doi.org/10.1186/s13731-016-0041-0

[38] Kessey, K.D. (2015) Assessing Credit Risk Management Practices in the Banking Industry of Ghana: Processes and Challenges. Global Journal of Management and Business Research: C Finance, 15, 1-10.

[39] Haron, H., Said, S.B., Jayaraman, K. and Ismail, I. (2013) Factors Influencing Small Medium Enterprises (SMES) in Obtaining Loan. International Journal of Business and Social Science, 4, 182-195.

[40] Bhatt, N. (2012) Financing of SMEs and Credit Risk: The Inevitable 5Cs. Journal of Commerce and Trade, 7, 13-17.

[41] Hashemi, R. (2013) The Impact of Capital Structure Determinants on Small and Medium Size Enterprise Leverage an Empirical Study of Iranian SMEs. Master Dissertation, Södertörn University, Huddinge.

[42] Du, J., Bian, C. and Gan, C. (2017) Bank Competition, Government Intervention and SME Debt Financing. China Finance Review International, 7, 478-492. https://doi.org/10.1108/CFRI-02-2017-0007

[43] Adeyeye, P.O., Azeez, B.A. and Aluko, O.A. (2016) Determinants of Small and Medium Scale Enterprises Financing by the Banking Sector in Nigeria: A Macroeconomic Perspective. Investment Management and Financial Innovations, 13, 170-175. https://doi.org/10.21511/imfi.13(1-1).2016.04

[44] Jenkins, H. and Hossain, M. (2014) An Analysis of the Macroeconomic Conditions Required for SME Lending: Evidence from Turkey and Other Emerging Market Countries. Panoeconomicus, 64, 77-92. https://doi.org/10.2298/PAN140213008J

[45] Kwaning, C.O., Nyantakyi, K. and Kyereh, B. (2015) The Challenges behind SMEs' Access to Debts Financing in Ghanaian Financial Market. International Journal of Small Business and Entrepreneurship Research, 3, 16-30.

[46] Fatoki, O. (2014) Factors Influencing the Financing of Business Start-ups by Commercial Banks in South Africa. Mediterranean Journal of Social Sciences, 5, 94-100. https://doi.org/10.5901/mjss.2014.v5n20p94

[47] Kusi, B.A., Agbloyor, E.K., Ansah-Adu, K. and Dako, A.G. (2017) Bank Credit Risk and Credit Information Sharing in Africa: Does Credit Information Sharing Institutions and Context Matter? Research in International Business and Finance, 42, 1123-1136. https://doi.org/10.1016/j.ribaf.2017.07.047

[48] Soedarmono, W., Sitorus, D. and Tarazi, A. (2017) Abnormal Loan Growth, Credit Information Sharing and Systemic Risk in Asian Banks. Research in International Business and Finance, 42, 1208-1218. https://doi.org/10.1016/j.ribaf.2017.07.058

[49] Nasr, S. (2010) Enhancing Access to Finance for Micro and Small Enterprises in Egypt. 10th Global Conference on Business and Economics, Italy, 15-16 October 2010. http://www.gcbe.us/10th_GCBE/data/confcd.htm

[50] Youssef, I. (2014) Small and Medium Enterprises and Access to Finance in Egypt. Master Thesis, The American University, Cairo.

[51] ElSaid, H. (2010) Access to Finance, Forms of Financing for SMEs in Egypt. Centeral Bank of Egypt, Egytian Banking Institute, SME Unit Publications, First Series.

[52] Gamage, P. (2015) Bank Finance for Small and Medium-Sized Enterprises in Sri Lanka: Issues and Policy Reforms. Studies in Business and Economics, 10, 32-43. https://doi.org/10.1515/sbe-2015-0018 
[53] Zeneli, F. and Zaho, L. (2014) Financing SMEs in Vlora City, Albania: Between Game Theory and Lack of Information. Procedia-Social and Behavioral Sciences, 150, 126-131. https://doi.org/10.1016/j.sbspro.2014.09.016 https://www.sciencedirect.com/science/article/pii/S1877042814050654

[54] Kalya, E. (2013) The Relationship between Selected Supply Side Factors and Lending to Small and Medium Enterprises by Commercial Banks in Kenya. Master Dissertation, University of Nairobi, Nairobi.

[55] Raaijmakers, L.G., Bessems, K.M., Kremers, S.P. and Assema, P.V. (2009) Breakfast Consumption among Children and Adolescents in the Netherlands. European Journal of Public Health, 20, 318-324. https://doi.org/10.1093/eurpub/ckp191

[56] Saunders, M., Lewis, P. and Thornhill, A. (2016) Research Methods for Business Students. 7th Edition, Pearson, Harlow.

[57] Cooper, D.R. and Schindler, P.S. (2014) Business Research Methods. 12th Edition, McGraw Hill International Edition, New York.

[58] Hair, J.F., Black, W.C., Babin, B.J. and Anderson, R.E. (2010) Multivariate Data Analysis. Seventh Edition, Prentice Hall, Upper Saddle River. 